\title{
Hubungan Pengetahuan Mencuci Tangan dengan Kejadian Diare pada Siswa Kelas IV-VI SDN 11 Lubuk Buaya Padang
}

\author{
Nur Afany ${ }^{1}$, Rosfita Rasyid ${ }^{2}$, Yulistini $^{3}$
}

\begin{abstract}
Abstrak
Diare menduduki urutan ke 9 dari 10 penyakit infeksi terbanyak di Padang dengan kejadian tertinggi di Kelurahan Lubuk Buaya. Diare ditularkan secara faecal oral dimana tangan menjadi salah satu faktor media penularan. Mencuci tangan pakai sabun merupakan salah satu upaya pencegahan infeksi yang dapat mengurangi insiden diare $>50 \%$. Tujuan penelitian ini adalah untuk mengetahui hubungan antara pengetahuan mencuci tangan dan kejadian diare pada siswa kelas 4 sampai 6 SDN 11 Lubuk Buaya Padang. Penelitian ini merupakan studi analitik dengan cross sectional study yang dilakukan dari Agustus 2013 sampai November 2013 dengan pengambilan sampel secara multistage random sampling. Hasil studi menunjukkan terdapat jumlah kejadian yang sama banyak antara siswa yang pernah diare dan siswa yang tidak pernah diare, kejadian diare banyak terdapat pada siswa kelas VI SD. Sebagian besar siswa (93\%) berpengetahuan baik mengenai mencuci tangan dengan cara baik dan benar dimana $50,4 \%$ siswa diantaranya tidak pernah diare dalam enam bulan terakhir dan 49,6\% siswa sisanya pernah mengalami diare enam bulan terakhir. Analisis statistik menunjukkan tidak terdapat hubungan yang bermakna antara pengetahuan mencuci tangan dengan kejadian diare. Kejadian diare pada siswa kelas IV-VI SDN 11 Lubuk Buaya Padang ini berkaitan dengan keadaan sanitasi lingkungan dan konsumsi jajanan yang tidak higienis.
\end{abstract}

Kata kunci: diare, pengetahuan mencuci tangan, anak

\begin{abstract}
Diarrhea ranks is 9th highest infectious disease in Padang with the highest incidence in the Lubuk Buaya Padang. Diarrhea is transmitted by fecal-oral which main transmitted media by hand. Hands washing with soap is an effort to prevent infection with decrease incidence of diarrhea $>50 \%$. The objective of this study was to determine relationship between knowledge of hands washing and the incidence of diarrhea in the 4 until 6 grade students of SDN 11 Lubuk Buaya Padang. This research was analytic method with cross sectional study during August 2013 until November 2013 with multistage random sampling. There was similar comparison between students who had diarrhea and students who never diarrhea with the highest incidence of class V. Most of students (93\%) had a good knowledge about good hand washing and correct, 50,4\% among never diarrhea in last six month and the remaining 49,6\% had experienced diarrhea in last six month. According to statistics there is no significant relation between knowledge of hands washing with the incidence of diarrhea. The incidence of diarrhea in the IV-VI grade students related with environment sanitation and consumption not hygienic food.
\end{abstract}

Keywords: diarrhea, knowledge of hands washing, children

Affiliasi penulis: 1. Prodi Profesi Dokter FK Unand (Fakultas Kedokteran Universitas Andalas Padang), 2. Bagian IImu Kesehatan Masyarakat FK Unand, 3. Bagian Mikrobiologi FK Unand.

Korespondensi: Nur Afany,Email: fany_14dct@hotmail.com,Telp: 085363352089

\section{PENDAHULUAN}

Diare adalah buang air besar (defekasi) dengan tinja berbentuk cair atau setengah cair (setengah padat) dimana kandungan air tinja lebih banyak dari biasanya lebih dari 200 gram atau $200 \mathrm{ml} / 24$ jam 
dengan frekuensi lebih dari 3 kali per hari. ${ }^{1}$ Diare merupakan penyakit infeksi menular yang mengakibatkan tingginya angka kesakitan hingga angka kematian terutama di negara berkembang seperti Indonesia. Diare merupakan penyebab kurang gizi yang penting terutama pada anak. ${ }^{2}$ Diare merupakan penyakit yang paling sering menyebabkan kematian di dunia yaitu lebih dari 1,5 juta anak per tahun. $^{3} \quad$ Angka kesakitan diare di Indonesia pada tahun 2010 adalah 411 penderita per 1000 penduduk, sebelumnya mengalami penurunan dari tahun 2006 yaitu 423 penderita per 1000 penduduk dan jumlah kasus diare, ditemukan sekitar 213.435 penderita dengan jumlah kematian 1.289 dan sebagian besar (70-80\%) terjadi pada anak-anak. ${ }^{4}$

Penyakit diare sampai saat ini menduduki urutan ke-9 dari 10 penyakit infeksi yang sering menyebabkan angka kesakitan cukup tinggi di Padang dengan 10.282 kasus (4,1\%). Kelompok umur terbanyak adalah lebih dari 5 tahun yaitu sebanyak 6898 kasus (59.2 \%). Khususnya kelurahan Lubuk Buaya memiliki kejadian diare yang tinggi dari kelurahan lain yang ada di Padang, baik pada dewasa dan anak yaitu 1436 kasus dari 165.980 penduduk. ${ }^{5} \mathrm{Di}$ Kelurahan Lubuk Buaya terdapat sekitar 3 Sekolah Dasar yaitu SDN 11, SDN 02 dan SDN 38 yang memiliki angka kejadian diare yang cukup tinggi untuk umur $>5$ tahun $^{5}$

Ada lebih dari $90 \%$ diare disebabkan karena infeksi, sedangkan sekitar $10 \%$ karena sebab lain antara lain obat-obatan, bahan toksik, iskemik dan sebagainya. ${ }^{6}$ Penyakit infeksi diare ditularkan secara faecal-oral melalui makanan dan minuman yang tercemar oleh feses atau bakteri atau virus yang menyebabkan diare, serta melalui kontak dari orang ke orang atau berkontak langsung atau dengan tangan yang terkontaminasi dengan feses yang terinfeksi. ${ }^{7}$

Tangan merupakan pembawa utama kuman penyakit yang dapat menjadi perantara infeksi silang, oleh karena itu sangat penting untuk diketahui dan diingat bahwa perilaku cuci tangan pakai sabun merupakan perilaku sehat yang sangat efektif untuk mencegah penyebaran berbagai penyakit menular seperti diare. ${ }^{8}$ Studi epidemiologi menunjukkan bahwa faktor risiko diare yang paling penting adalah perilaku yang mendorong seseorang untuk berkontak dengan faecalmatter (feses) termasuk buang air besar yang tidak pada tempatnya, tidak mencuci tangan dengan bersih setelah buang air besar atau setelah berkontak langsung dengan feses dan sebelum memegang atau menyiapkan makanan. ${ }^{7}$

Salah satu upaya yang dapat dilakukan untuk menurunkan angka kejadian diare adalah perilaku cuci tangan pakai sabun. ${ }^{9}$ Perilaku mencuci tangan dengan sabun khususnya setelah berkontak dengan feses dapat menurunkan insiden diare hingga $42-47 \%{ }^{10}$ Saat ini hanya sekitar $17 \%$ anak usia sekolah di desa Senuro Timur yang mencuci tangan pakai sabun dengan benar, padahal anak usia tersebut rentan terhadap penyakit seperti diare. ${ }^{9}$ Praktek perilaku mencuci tangan yang baik didasari oleh pengetahuan yang baik mengenai cara mencuci tangan dengan baik dan benar.

Siswa usia 10-12 tahun yang terpresentatif pada kelas IV,VdanVI merupakan sasaran yang paling tepat untuk dilakukan wawancara dengan kuisioner karena pada usia tersebut minat belajar anak yang tinggi di dukung oleh ingatan anak yang mencapai intensitas paling besar dan paling kuat, serta kemampuan dalam menangkap dan memahami materi yang diberikan, termasuk informasi mengenai pengetahuan tentang mencuci tangan. ${ }^{11}$

\section{METODE}

Penelitian yang dilakukan bersifat cross sectional pada Agustus 2013 sampai November 2013. Lokasi penelitian di SDN 11 Lubuk Buaya Padang. Sampel penelitian adalah siswa SDN 11 Lubuk Buaya Padang kelas IV-VI yang berjumlah 128 siswa. Cara pengambilan sampel yaitu Multistage Random Sampling. Data yang dikumpulkan diolah dengan menggunakan metode chi-square test.

\section{HASIL dan PEMBAHASAN}

Hasil penelitian yang dilakukan terhadap siswa kelas IV-VI SDN 11 Lubuk Buaya Padang mendapatkan distribusi siswa kelas IV-VI yang mengalami diare dan tidak diare pada Tabel 1. Hasil penelitian yang didapatkan adalah frekuensi siswa yang pernah diare dalam enam bulan terakhir dan 
siswa yang tidak pernah diare dalam enam bulan terakhir memiliki perbandingan yang sama banyak yaitu 64 siswa pernah diare dan 64 siswa lainnya tidak pernah diare. Tabel 2 memperlihatkan frekuensi siswa yang pernah diare dalam enam bulan terakhir banyak terdapat pada kelas V SD $(56,5 \%)$ sedangkan siswa yang tidak pernah diare dalam enam bulan terakhir banyak ditemukan pada kelas IV SD (59,5\%).

Distribusi pengetahuan mencuci tangan pada siswa kelas IV-VI penderita diare dan bukan penderita diare dapat dilihat pada Tabel 3. Hasil penelitian ini mendapatkan sebagian besar siswa kelas IV-VI (93\%) memiliki pengetahuan yang baik mengenai mencuci tangan sedangkan sisanya (3,9\%) siswa memiliki pengetahuan cukup dan $(3,1 \%)$ siswa memiliki pengetahuan kurang mengenai mencuci tangan.Tabel 4 memperlihatkan distribusi pengetahuan mencuci tangan pada siswa kelas IV-VI, pengetahuan yang baik banyak ditemukan pada siswa kelas VI $(97,5 \%)$ yang terwakili oleh umur 11-12 tahun sedangkan siswa yang memiliki pengetahuan yang kurang banyak ditemukan pada kelas $\mathrm{V}(4,3 \%)$ yang terwakili oleh umur 10-11 tahun.

Hubungan pengetahuan mencuci tangan dengan kejadian diare pada siswa kelas IV-VI SDN 11 Lubuk Buaya Padang dapat dilihat pada Tabel 5. Hasil penelitian ini didapatkan bahwa sebagian besar siswa (93\%) yang memiliki pengetahuan baik mengenai mencuci tangan, 49,6\% siswa diantaranya pernah diare dalam enam bulan terakhir dan $50,4 \%$ siswa sisanya tidak pernah diare dalam enam bulan terakhir. Hasil uji statistik menunjukkan nilai $p=0,246(p>0,05)$ dengan demikian tidak terdapat hubungan bermakna antara hubungan pengetahuan mencuci tangan dengan kejadian diare pada siswa kelas IV-VI SD.

Tingginya frekuensi kejadian diare menandakan bahwa terjadi peningkatan faktor risiko yang menyebabkan terjadinya diare. ${ }^{3}$ Faktor risiko yang dimaksud seperti tidak menerapkan kebiasaan mencuci tangan pakai sabun sebelum memberi makan, setelah buang air besar, serta ketersediaan air bersih dan MCK yang tidak memadai. ${ }^{12}$ Tingginya kejadian diare pada siswa kelas IV-VI SDN 11 Lubuk Buaya Padang dapat disebabkan oleh banyak hal, seperti tidak menerapkan kebiasaan mencuci tangan pakai sabun, kebiasaan konsumsi jajanan yang kurang higienis, ketersediaan jamban yang kurang memadai pada lingkungan rumah serta ketersediaan air bersih dan sehat yang tidak memadai. Sikap dan praktek siswa terhadap mencuci tangan tidak dilakukan dalam penelitian ini.

Hasil penelitian ini yaitu mengenai hubungan pengetahuan mencuci tangan dengan kejadian diare pada siswa kelas IV-VI SDN 11 Lubuk Buaya Padang didapatkan bahwa 93\% siswa yang memiliki pengetahuan baik mengenai mencuci tangan dengan cara baik dan benar ternyata $50,4 \%$ siswa diantaranya tidak pernah mengalami diare dalam enam bulan terakhir dan $49,6 \%$ siswa pernah mengalami diare dalam enam bulan terakhir. Berdasarkan uji statistik didapatkan nilai $p>0,05$ sehingga tidak terdapat hubungan yang bermakna antara pengetahuan mencuci tangan dengan kejadian diare pada siswa kelas IV-VI SDN 11 Lubuk Buaya Padang.

Penelitian ini berbeda dengan hasil penelitian tahun 2013 yang menemukan bahwa terdapat hubungan antara perilaku cuci tangan dengan terjadinya diare pada anak usia sekolah dasar. ${ }^{8}$ Disararankan bahwa perilaku mencuci tangan dengan sabun khususnya setelah berkontak dengan feses dapat menurunkan insiden diare hingga $42 \%-47 \%$. ${ }^{10}$ Praktek perilaku mencuci tangan dipengaruhi oleh pengetahuan yang dimiliki seseorang mengenai mencuci tangan serta ketersediaan fasilitas yang baik untuk mencuci tangan seperti air bersih yang mengalir dan ketersediaannya sabun.

Tidak adanya hubungan antara pengetahuan mencuci tangan dengan kejadian diare pada siswa kelas IV-VI SDN 11 Lubuk Buaya Padang dapat terjadi karena terdapat faktor lain yang tidak diteliti dalam penelitian ini yang mempengaruhi kejadian diare yaitu sikap dan praktek siswa-siswi terhadap mencuci tangan. Faktor yang mempengaruhi kejadian diare selain faktor perilaku, terdapat faktor lingkungan yaitu ketersediaan air bersih dan MCK jamban yang sehat serta kebersihan lingkungan dan pribadi yang buruk seperti kurangnya praktek kebersihan pribadi.

Hasil observasi yang dilakukan di tempat penelitian, ditemukan tidak terdapatnya sarana yang baik untuk mencuci tangan seperti tidak adanya sabun, wastafel serta air bersih yang tidak selalu 
mengalir. Selain itu, terdapat penjualan makanan dan minuman di sekitar lingkungan sekolah yang tidak higienis dan penggunaan air minum yang tidak memenuhi syarat kesehatan dapat menjadi faktor penyebab terjadinya diare terutama pada anak-anak sekolah dasar. Hasil observasi ini sama dengan hasil penelitian tahun 2008 yang menemukan adanya hubungan kondisi sarana air bersih dengan kejadian diare. $^{13}$

\section{DAFTAR TABEL}

Tabel 1. Distribusi frekuensi dan persentase kejadian diare murid kelas IV-VI SDN 11 Lubuk Buaya Padang

\begin{tabular}{lcc}
\hline $\begin{array}{c}\text { Kejadian } \\
\text { Diare }\end{array}$ & $\mathbf{f}$ & $\%$ \\
\hline Pernah & 64 & 50 \\
Tidak pernah & 64 & 50 \\
\hline Total & 128 & 100 \\
\hline Keterangan : $f=$ frekuensi,$\%$ persentasi kejadian
\end{tabular}

Tabel 2. Distribusi frekuensi dan persentase kejadian diare siswa-siswi penderita diare dan bukan penderita diare berdasarkan kelas

\begin{tabular}{lcccccc}
\hline \multirow{2}{*}{ Kelas } & \multicolumn{9}{c}{ Kejadian Diare } \\
\cline { 2 - 7 } & Pernah & \multicolumn{2}{l}{ Tidak Pernah } & \multicolumn{2}{l}{ Total } \\
\cline { 2 - 7 } & $\mathbf{f}$ & $\%$ & $\mathbf{f}$ & $\%$ & $\mathbf{n}$ & $\%$ \\
\hline Kelas IV & 17 & 40,5 & 25 & 59,5 & 42 & 100 \\
Kelas V & 26 & 56,5 & 20 & 43,5 & 46 & 100 \\
Kelas VI & 21 & 52,5 & 19 & 47,5 & 40 & 100 \\
\hline
\end{tabular}

Keterangan $: \mathrm{f}=$ frekuensi,$\%=$ persentase kejadian, $\mathrm{n}=$ jumlah

Tabel 3. Distribusi frekuensi dan persentase mengenai pengetahuan mencuci tangan pada siswa-siswi kelas IV-VI SDN 11 Lubuk Buaya Padang

\begin{tabular}{lcc}
\hline $\begin{array}{l}\text { Pengetahuan } \\
\text { mencuci } \\
\text { tangan }\end{array}$ & $\mathbf{f}$ & $\%$ \\
\hline Baik & 119 & 93 \\
Cukup & 5 & 3.9 \\
Kurang & 4 & 3.1 \\
\hline Total & 128 & 100 \\
\hline Keterangan : $\mathrm{f}=$ frekuensi , \% $=$ persentase kejadian
\end{tabular}

Tabel 4. Distribusi frekuensi dan persentase mengenai pengetahuan mencuci tangan pada siswa-siswi penderita diare dan bukan penderita diare berdasarkan kelas

\begin{tabular}{lcccccc}
\hline \multirow{2}{*}{ Kelas } & \multicolumn{4}{c}{ Pengetahuan Mencuci Tangan } \\
\cline { 2 - 7 } & \multicolumn{2}{c}{ Baik } & \multicolumn{2}{c}{ Cukup } & \multicolumn{2}{c}{ Kurang } \\
\cline { 2 - 7 } & $\mathbf{f}$ & $\%$ & $\mathbf{f}$ & $\%$ & $\mathbf{f}$ & $\%$ \\
\hline KelasIV & 39 & 92,9 & 2 & 4,8 & 1 & 2,4 \\
Kelas V & 41 & 89,1 & 3 & 6,5 & 2 & 4,3 \\
Kelas VI & 39 & 97,5 & 0 & 0 & 1 & 2,5 \\
\hline Keterangan : $\mathrm{f}=$ frekuensi , \% & $=$ persentase kejadian, \\
$\mathrm{n}$ = jumlah
\end{tabular}

Tabel 5. Hubungan pengetahuan mencuci tangan dengan kejadian diare pada siswa-siswi kelas IV-VI SDN 11 Lubuk Buaya Padang

\begin{tabular}{lccccc}
\hline $\begin{array}{c}\text { Pengetahuan } \\
\text { Mencuci } \\
\text { Tangan }\end{array}$ & \multicolumn{2}{c}{$\begin{array}{c}\text { Pernah } \\
\text { Diare }\end{array}$} & \multicolumn{2}{c}{$\begin{array}{c}\text { Tidak Pernah } \\
\text { Diare }\end{array}$} & P \\
\cline { 2 - 6 } Baik & 59 & 49,6 & 60 & 50,4 & \\
Cukup & 4 & 80 & 1 & 20 & $\mathbf{0 , 2 4 6}$ \\
Kurang & 1 & 25 & 3 & 75 & \\
\hline $\begin{array}{l}\text { Keterangan : } \mathrm{f}=\text { frekuensi, } \%=\text { persentasi kejadian, } \\
\mathrm{n}=\text { jumlah, } \mathrm{p}=\text { nilai } \mathrm{p}\end{array}$
\end{tabular}

\section{SIMPULAN}

Tidak ada hubungan yang bermakna antara pengetahuan mencuci tangan dengan kejadian diare pada siswa kelas IV-VI SDN 11 Lubuk Buaya Padang.

\section{DAFTAR PUSTAKA}

1. Simadibrata K, Daldiyono. Gastroenterologi. Dalam: Sudoyono WA, Setiyohadi B, Alwi I, K Simadibrata $M$, Setiatis $S$, editor (penyunting). Buku ajar ilmu penyakit dalam jilid I. Edisi ke-5. Jakarta: Interna Publishing; 2009.hlm.548-56.

2. Widoyono. Penyakit tropis epidemiologi, penularan, pencegahan dan pemberantasannya. Semarang: Erlangga;2008.

3. WHO-UNICEF. Diarrhea: why children are still dying and what can be done. WHO Library Cataloging-in-Publication Data. 2009;1-68.

4. Departemen Kesehatan RI. Profil Kesehatan Indonesia 2009. Tersedia dari: URL: HYPERLINK http://www.depkes.go.id. 
5. Dinas Kesehatan Kota Padang. Profil kesehatan Kota Padang 2011. Laporan Tahunan. 2012;1-283.

6. Seiawan B. Tropik Infeksi. Dalam: Sudoyono WA, Setiyohadi B, Alwi I, K Simadibrata M, Setiasih, editor (penyunting). Buku ajar ilmu penyakit dalam jilid III. Edisi ke-5. Jakarta: Interna Publishing; 2009.hlm.2836-42.

7. Ejemot Nwadiaro RI, Ehiri JE, Meremikwu MM, Critchley JA. Hand washing for preventing diarrhoea (review). The Cochrane Collaboration. 2012;2-43.

8. Rompas JM, Tuda J, An PT. Hubungan antara perilaku mencuci tangan pakai sabun dengan terjadinya diare pada anak usia sekolah di SDN GMIM dua Kecamatan Tareran. Manado: Universitas Sam Ratulangi; 2013.

9. Fajar NA, Misnaniarti. Hubungan pengetahuan dan sikap terhadap perilaku cuci tangan pakai sabun di Desa Senuro Timur. Palembang: Fakultas
Kesehatan Masyarakat Universitas Sriwijaya. 2011;5(Pt 1):1-7.

10. Curtis, Cairncross. Effect of washing hands with soap on diarrhoea risk in the community: a sistematic review. Tersedia dari: URL: HYPERLINK: www.ncbi.nlm.nih.gov/pubmed/ 12726975.

11. Putri I. Studi komparasi pendidikan kesehatan multimedia pembelajaran dan metode demonstrasi terhadap tindakan mencuci tangan pakai sabun pada siswa kelas V SDN 20 Dadok Tunggul Hitam dan SDN 23 Pasir Sebelah Padang (skripsi). Padang: Universitas Andalas; 2012.

12. Kementerian Kesehatan RI. Situasi diare di Indonesia. Profil Kesehatan Indonesia 2011;1-44.

13. Winova. Hubungan kondisi sarana air bersih dan perilaku dengan kejadian diare di Kenagari Taruang-Taruang Kecamatan IX Koto Sungai Lasi Tahun 2008 (skripsi). Padang: Universitas Andalas; 2008. 